2. Olga Kuprieieva. Psychological Characteristics of Self-realization of Students with Disabilities. Social Welfare: Interdisciplinary Approach. 2015. Vol. 2 No 5. P. 64-74. http://socialwelfare.eu/index.php/sw/article/view/228

3. Ryan R. M. Self-determination theory: Basic Psychological Needs in Motivation Development and Wellness. New York, NY: Guilford Press. 2017. $756 \mathrm{p}$.

4. Seligman M. E., Scikszentmihalyi M. Positive psychology. An introduction. American Psychologist. 2000. Vol. 55 (1). P. 5-14. https://doi.org/10.1037/0003-066X.55.1.5

DOI https://doi.org/10.30525/978-9934-588-80-8-1.15

\title{
ГЕНДЕРНІ ОСОБЛИВОСТІ МІЖОСОБИСТІСНИХ ВІДНОСИН КАР'СРНО-УСПІШНИХ ЖІНОК
}

\author{
Літвінова О. В. \\ кандидат психологічних наук, \\ дочент кафедри психології, педагогіки та філософії \\ Кременчуцький начіональний університет \\ імені Михайла Остроградського
}

Герасимова А. Б.

здобувач другого (магістерського) рівня спеціальності «Психологія»

Кременчуцький національний університет

імені Михайла Остроградського

м. Кременчук, Полтавська область, Украӥна

Метою роботи $\epsilon$ аналіз емпіричних студій щодо гендерних особливостей міжособистісних відносин жінок, які $є$ успішними в кар'єрі. У сучасних умовах якісно новим образом постає проблема розвитку і використання людського потенціалу, пред’являються більш високі вимоги до самостійності, ініціативності, підприємливості людини, що викликані змінами в суспільстві. Кар'єра являє собою безперервний процес успішного просування по сходах адміністративної, соціальної, професійної, майнової та іншої ієрархії з метою досягнення бажаного статусу і відповідного йому рівня і якості життя. У суспільній свідомості кар'єрне просування і управління в більшій мірі пов'язане 3 представниками чоловічої статі. Разом 3 тим, посилення жіночої емансипації призводить до того, що багато жінок хочуть бути 
самостійними і незалежними, мати можливість проявити свої здібності в професійній діяльності, зробити кар'єру.

Дискусії з приводу соціального статусу, суспільного становища жінки були актуальними впродовж всього періоду розвитку людства, проте варто зауважити, що на сьогоднішній день становище жінки i надалі залишається темою для обговорень як в науковому, так і в побутовому житті.

Є. О. Могільовкін дотримується розуміння кар'єри 3 позицій психолого-акмеологічного підходу і розглядає кар'єрне просування не тільки (і не стільки) як просування щаблями організаційної ієрархії, а як процес реалізації людиною себе, своїх можливостей в умовах професійної діяльності, досягнення особистістю свого «акме» [5].

Російська дослідниця М. О. Ревіна, узагальнюючи результати професійного шляху жінки, прийшла до висновку, що для жінки ії шлях до управлінської кар'єри пов'язаний із подоланням численних забобонів, в той час як для чоловіків - з реалізацією численних можливостей. Вона виділяє декілька видів бар'єрів, з якими зіштовхується жінка на шляху до успішної кар'єри: культурні, освітні, юридичні та психологічні [4]. Останні проявляються, з однісї сторони в негативному настрої чоловіків, які не бажають працювати під началом жінкикерівника, з іншої сторони, в сумнівах самих жінок у своїх здібностях поєднувати сім'ю та роботу, недолік інформації про механізми кар'єрного просування, установка на соціальне схвалення, що пов'язане із традиційно жіночою рольовою поведінкою, острахом успіху, небажаних наслідків для значущих відносин.

Для вивчення психологічних особливостей міжособистісних відносин жінок, які є успішними в кар'єрі було проведене констатувальний експеримент, експериментальну вибірку якого склали 30 жінок, які працюють в закладах освіти, мають вищу категорію та виконують певні управлінські функції. В якості психодіагностичного інструментарію було застосовано опитувальник Сандри Бем; опитувальник задоволеності шлюбом $\mathrm{B}$. В. Століна; тест-опитувальник К. Томаса; методика діагностики особистісної установки «альтруїзмегоїзм» М. Фетіскіна.

За результатами дослідження гендерної ідентичності жінки розподілилися наступним чином: $50 \%$ мають андрогінний тип ідентичності, $30 \%$ - фемінний та $20 \%$ - маскулінний. Такий розподіл можна вважати позитивним, тобто українські жінки не позбавлені жіночності, а маскулінізація, про яку говорять дослідники, не $\epsilon$ тотальною і пов'язана 3 підвищенням рівня андрогінності, що $\epsilon$ проявом збалансованої внутрішньої природи та соціально-психоло- 
гічної адаптації. Андрогінність особливо $є$ позитивною для жінок, які просуваються по кар'єрі, адже дана властивість сприяє можливості мати більше поведінкових стратегій, проявляти гнучкість у їх використанні для досягнення результатів діяльності.

Дослідження задоволеності шлюбними відносинами у жінок мають такий розподіл: для $56 \%$ опитаних жінок характерним $є$ високий рівень задоволеності відносинами із шлюбним партнером, $27 \%$ - середній рівень і $17 \%$ - низький. Найбільш задоволеними сімейним життям виявилися фемінні жінки. Такий результат є логічним, оскільки для фемінної жінки традиційно родина $\epsilon$ найважливішою сферою вкладання душі та особистісного потенціалу. Менше задоволені сімейним життям андрогінні та маскулінні жінки. Психоаналітична література описує приклади рольових конфліктів у жінок, зайнятих в професійній сфері, які викликані «почуттям провини працюючої жінки». Слідства відчуття провини проявляються в значущих галузях життя: в подружніх та дитячо-батьківських відносинах, взаємовідносинах на роботі на відношенні до себе [3].

Занадто велика залученість до роботи не відповідає традиційній жіночій ролі, тому працюючі жінки часто відчувають тривогу та почуття провини. Можливо, такі почуття, а також тещ разом із тяжкими обов'язками управлінської функції жінка повинна нести на собі ще й сімейні та домашні турботи, змушують багатьох жінок обирати такі шляхи розвитку кар'єри, які б звели до мінімум всі ці протиріччя. Пауелл і Маніеро відмічають, що деякі 3 чоловіків розглядають сім'ю як обставину, яка впливає на їхнє просування по службі, тоді як більшість конфліктуючих ролей, які приходиться грати жінкам, що мають дітей, вливають на вибір ними своєї кар'єри [1]. Для більшості кар'єрно-успішних жінок професійні і сімейні ролі $\epsilon$ однаково значущими, що часто служить причиною рольового конфлікту «робота - сім'я» і призводить до дисгармонії в сімейних відносинах. Особливо цей конфлікт виражений у молодих жінок, які пробують поєднати процес активного розвитку професійної кар'єри із створенням і збереженням сім'ї, зазнаючи при цьому значну «рольову напругу». Побудова кар'єри часто супроводжується у жінок негативними емоційними переживаннями, пов'язаними із тиском 3 боку сім'ї чи керівництва, почуттям провини за неналежну увагу до своїх близьких, особливо до дітей, проблемою вибору «дитина кар'єра», відчуттям «не жіночності», що може негативно сказатися на їх психологічному стані.

Щодо стратегій поведінки в конфлікті, було виявлено, що для $30 \%$ жінок, типовим способом реагування на конфлікт є суперництво (i це 62 
переважно жінки, що мають маскулінний тип гендерної ідентичності); для $40 \%$ респондентів домінує співробітництво (це переважно жінки, для яких характерним $є$ андрогінний та фемінний типи); у $20 \%$ досліджуваних виявлено стратегію компромісу, яка проявляється у жінок $з$ андрогінним типом ідентичності; у $10 \%$ стратегія «відхід від конфлікту» - це жінки з фемінним типом. Такий спосіб реагування як уникнення не було виявлено.

Конфлікт може спричинити зміну системи відносин і цінностей. У конфліктній ситуації люди по-іншому сприймають реальність, вдаються до невластивих їм дій. У конфлікт переростає не будь-яка суперечність, а така, в якій сходяться найсуттєвіші потреби, прагнення, інтереси, цілі людей, соціальний статус, престиж особистості [2].

Результати дослідження щодо установок на альтруїзм-егоїзм в ситуації міжособистісного спілкування дали змогу констатувати, що альтруїзм має високі прояви лише у 20 \% (і це жінки з фемінним типом ідентичності), у $80 \%$ жінок переважає особистісна установка егоїзм. Потрібно зазначити, що діяльність, яка пов'язана 3 просуванням по кар'єрних сходах, наполегливості, цілеспрямованості вимагає акцентів на власних інтересах і «здоровий» егоїзм може бути помічником для здійснення власних амбіцій та власних досягнень жінки.

Отже, дослідження доводить, що жінки 3 андрогінним типом гендерної ідентичності можуть бути більш успішними у міжособистісніх відносинах, використовуючи стиль співробітництва та компромісу, вони орієнтовані на досягнення власних цілей, але при цьому не завжди задоволені шлюбними відносинами, адже їм може бути властивий так званий «рольовий конфлікт працюючої жінки». Жінки 3 фемінним типом гендерної ідентичності більше задоволені відносинами із шлюбним партнером, але стратегія відходу від конфліктів, орієнтація на альтруїзм можуть перешкоджати досягненням у професійній сфері. Маскулінні жінки в міжособистісних стосунках орієнтовані на боротьбу, на досягнення, для них характерним є низький рівень задоволеності шлюбними відносинами. Очевидно, що для маскулінних та андрогінних жінок робота має вищу суб'єктивну цінність $\mathrm{i}$ вони прикладають більше зусиль для досягнення успіху у професійній сфері. Фемінність і маскулінність сприяють самореалізації людини, але в кожному конкретному випадку успішність самореалізації залежить від міри їх вираження, співвідношення та статевої відповідності.

\section{Література:}

1. Введение в гендерные исследования: учеб. пособие для студентов вузов / И. В. Костикова и др.; под общ. ред. 
И. В. Костиковой; [2-е изд., перераб. и доп.]. М. : Аспект-Пресс, 2005. $255 \mathrm{c}$.

2. Визгина А. В., Пантилеев С. Р. Проявление личностных особенностей в самоописаниях мужчин и женщин. Вопросы психологии. 2001. № 3. С. 91-100.

3. Горностай П. П. Диагностика и коррекция ролевых конфликтов. Журнал практического психолога. 1999. № 1. С. 44-51.

4. Каширская И. К. Социально-психологический анализ основных источников информации и процесс гендерной социализации. Bonpocbl психологии. 2003. № 6. С. 8-11.

5. Літвінова О.В. Вплив гендерних стереотипів на професійне самовизначення : теоретичний аспект. Наукові Записки Ін-ту психологіi ім. Г. С. Костюка АПН Украӥни; За ред. С. Д. Максименка. К. : Главник, 2005. Вип. 26. Т. 3. С. 3-7.

DOI https://doi.org/10.30525/978-9934-588-80-8-1.16

\title{
ОСОБЕННОСТИ ОСОЗНАННОСТИ КАК ПРОЦЕССА И МЕТОДА
}

\author{
Мединцов И. В. \\ аспирант кафедры общей психологии \\ Киевский национальный университет имени Тараса Шевченко \\ 2. Киев, Украина
}

Для того, чтобы определенная процедура вошла в арсенал эмпирической клинической психологии, в настоящее время требуются две вещи: технология должна быть достаточно четко определена и должна оказаться полезной при надлежащем применении. Эти требования важны, но в конечном итоге недостаточны. Бывают случаи, когда технологии настолько эфективны, что одно только их воздействие оправдывает их положение, но в более естественной ситуации прогресс в этой области требует включения этих технологий в один или несколько научных отчетов по психопатологии для наличия доказательств важности указанных процессов и принципов.

Эмпирическая клиническая психология значительно недооценила эти моменты, но долгосрочный эфект такого подхода становится все более очевидным. Без научно-понятных процессов и принципов данные о технологиях собираются в постоянно растущую совокупностть без 